\title{
踵骨に生じた骨好酸球性肉芽腫の一例
}

長崎大学医学部整形外科
長 岡 徳 三・田 中 宏 和
岩 崎 勝 郎・鈴 木 良 平

長崎大学府属病院検査部病理

津 田 暢夫

\section{Case Report of Eosinophilic Granuloma in Calcaneus}

by

\author{
T. Nagaoka, H. Tanaka, K. Iwasaki \\ and R. Suzuki \\ Department of Orthopaedic Surgery Nagasaki University \\ School of Medicine

\section{N. Tsuda} \\ Pathologic Division, Central Diagnostic Laboratory, \\ Nagasaki University Hospital
}

\begin{abstract}
A solitary eosinophilic granuloma of bone is the most benign variant in Histiocytosis $X$. Any bone in the skeletal system may be affected in childhood, and common sites for bone lesions include the skull, the shafts of long bones, and the ilium. Only one case involving foot bone was reported by Campbell and Leupold during the last ten years. We documented a case of eosinophilic granuloma arising in the left calcaneus of one year and seven months old boy. Eight months after the curettage and bone graft from his mother's iliac bone, he was free from symptoms and there were neither local recurrences nor metastases even on X-ray examination.
\end{abstract}

は じめに

骨好酸球性肉芽腫の好発生部位は, 頭蓋骨, 長幹骨 骨幹部および腸骨などであり，その他種々の骨に発生. するととが報告されているが，足根骨に発生した症例 の報告は極めて稀れである. 今回, 我々は左踵骨に発 生した骨好酸球性肉芽腫を経験したので, 若干の文献 的考察を加えて報告する.

\section{症例}

症例. 1 歳 7 力月, 男子.

主訴：跛行

家族歴および既往歴：特記すべきととなし．

現病歴：昭和 57 年 6 月頃, 何ら誘引なく跛行が出 現した. 左踵骨部に, 軽度の腫脹と局所熱感を認めた
ため，近医を訪れX $\mathrm{X}$ 線検査にて左踵骨体部の骨透亮像 を指摘され，昭和 57 年 7 月 12 日当科を受診した.

全身的には，特に 異常所見はみられず，局所的に は, 左踵骨体部に軽度の腫脹と局所熱感を認めた。 X 線像では，左踵骨中央部にかなり大きな境界不整の骨 透亮像があり，一部骨皮質は消失していた．周辺の骨 硬化性変化は，わずかに認められた（図1）。

なお， 2 週間前に某医でとられたX線像と比較する かなり急速に病巣が拡大していると考えられた.

全身骨シンチグラムでは, 左踵骨以外に ${ }^{99 \mathrm{~m}} \mathrm{Tc}$ の 異常集積は認められず, 左踵骨では病変部に一致して cold area と, その周辺に中等度の ${ }^{99 \mathrm{~m}} \mathrm{Tc}$ の upTake の亢進が認められた.

血液・生化学的検査では, 白血球数の減少, アルカ リフォスファターゼや LDH の軽度上昇がみられた 
が, 末血の好酸球数は正常範囲であった. 血液・生化 学的検查では, 炎症性疾患は否定的であったが, X線 像上, 急速な病畄の拡大が認められたため, 腫瘍より 炎症性疾患の方をまず疑った，針生検で得た標本は， 黄褐色の肉芽様組織であり, 細菌培養は陰性, 組織学 的には，骨好酸球性肉芽腫が考えられた。

昭和 57 年 7 月 29 日, 病巣を搔爬し，母親の腸骨よ 採取した骨を移植した。病监内には生検標本と同様, 黄褐色調, 軟の肉芽様組織が允満し, 踵骨底部の骨皮 質は一部破壊消失していた，組織学的にも前回と同 様, 核が扁在する巨細胞を混じた組織球の増殖と好酸 球の散在性浸潤が認められた. 增殖した組織球には, 全く異型性は認められなかった（図 2).

以上より，左踵骨に生じた単発性骨好酸球性肉芽腫 と晾断した.

術後 8 力月の現在, 臨床的, $\mathrm{X}$ 線学的に特に再発を 思わせる所見はなく，移植した同種骨もよく同化して いる(図 3 ).

$$
\text { 考察 }
$$

骨好酸球性肉芽腫は, 組織球の増殖性変化を特徽之 した腫瘍性病変群，いわゅる Histiocytosis X の一 部分症と考えられている8 . しかしながら，真の腫瘍

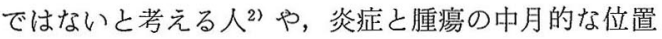
にあるものとして広義の炎症性腫瘍に属すると考える 人5) むいる.

また，その病因に関しては，ウイルス感染9 やウイ ルス感染に対する免疫アレルギー反応11) などが 考え られるとして，免疫学的に解明しようとする試みああ る ${ }^{10)}$ が，依然としてその本態は不明である.

本症例の場合, 汃なり急速に骨破壞性変化が進行し たとと，年齢が 1 歳 7 力月と低く，さらに他の部位に 同様な病変がないと考えられたととなどから, 腫瘍性 病変より炎症性病変を考えた。即ち, $1 \sim 2$ 週間の内 に急速に増大する病変に対しては，まず炎症性疾患を 考光る必要があるが，このことからみても，本腫瘍を 単なる良性腫㰾と片付けてしまうには疑問が残る。

さて, 発生部位に関して, Hunter ら4) は, 手関 節，足関節より中枢の骨であればいかなる骨にも発生 すると述べ，手抢よび足の骨には稀れであるととを表 現している. 又, 他の文献を調べてみても, 手および 足根骨に発生した報告は殆んごなく，最近 10 年間の 文献では, Campbell \& Leupold (1973)1) の 23 歳,

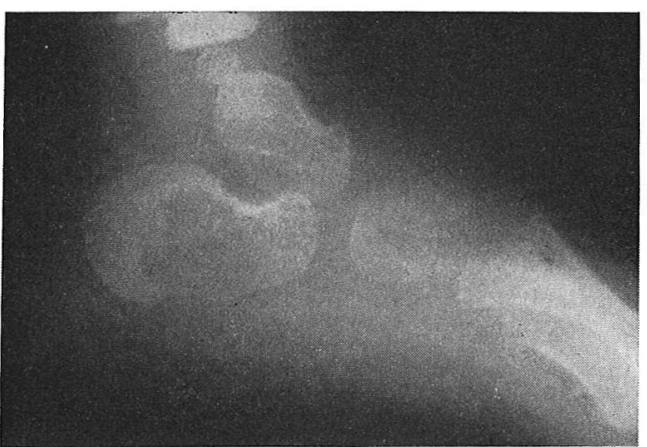

図 1 初䛦㭙の $\mathrm{X}$ 線像

左踵骨体部骨透亮像がみられる。境界は不鮮 明, 辺縁の骨硬化像はわずかにみられる。一部骨 皮質の破壊がみられる。

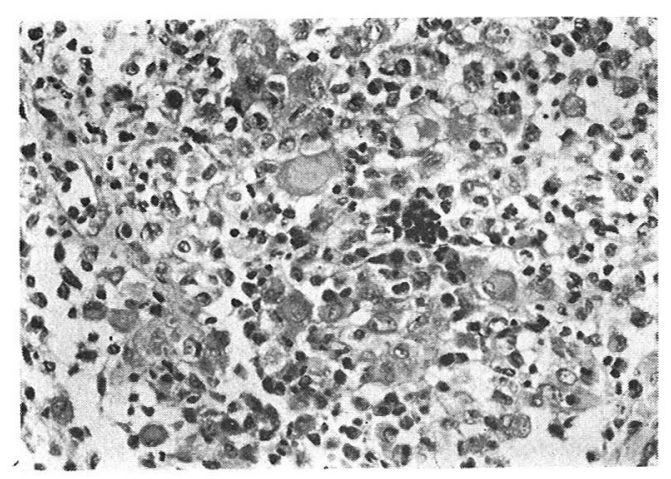

図 2 蛋爬時の踵骨骨髄

核が扁在する巨細胞を混じた組織球の浸潤。小 型の黑い細胞は好酸球. (X320)

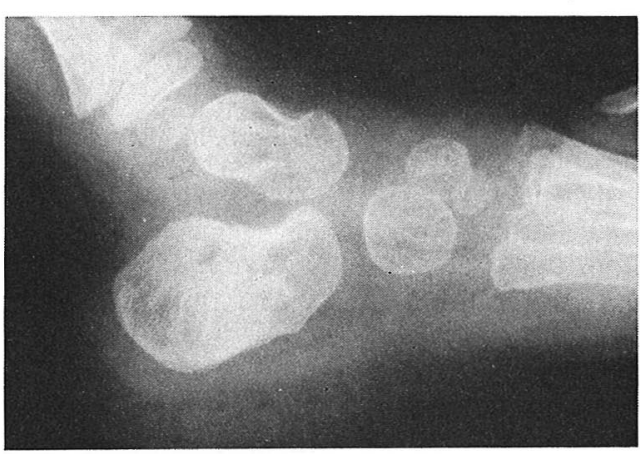

図 3 術後 8 力月の $\mathrm{X}$ 線像

移植骨はよく同化しており, 再発を思わせる所 見はない. 
男性で右踵骨結節部に発生した一症例のみである。こ の症例は, 病巣搔爬を受け, 組織学的に骨好酸球性肉 芽腫之診断され，その後，再発はみられていない．

何故, 本症が手抢よび足根骨任発生するととが稀れ であるかは不明であるが，本論文では，本症がこの様 な骨にあ単発しうるあのであるととを改めて認識し報 告した.

なお，Histiocytosis X の病型分類のうち，臨床的 所見および経過を重視した Lichtenstein の分類9) か らすれば，本症例は，「骨に単発または多発性に発生 し最も治癒傾向が強く, 時に自然治癒もみられる型」 の中に入るあのと考えられ，時間が経過すると lipidladen macrophage の出現や線維化がみられる ${ }^{3)}$.

しかしながら，いくら良好な経過をとり，放置して いても線維化して治癒する ${ }^{3)}$ と考えられても，本症の 様汇急速汇進行する骨破壊が特に荷重骨にはみられれ ば，手をてまねいて見ているわけにはいかない，自然 経過はどうなるかという学問的興味は津々ながら，や はり早急な病巣搔爬，骨移植も止むを得ないところで あろう。

本症例は, 術後 8 力月の現在, 移植した同種骨はよ く同化し置換されてきていると考えられ，再発所見は なく良好な経過をとっている。しかし，Lahey は， 発症年齢が 3 歳以下の症例は予後が不良であったと報 告し, Histiocytosis X の予後因子として organ dysfunction の有無を重視している677). 本症例は, 現在 organ dysfunction むなく, 治瘉したものと考 えられるが，発症年齢が 1 歳 7 カ月であり，いましば らく再発および全身骨の追跡を行う必要があると考え ている.

\section{考文 献}

1) Campbell, C. J. and Leupold, R. G.: Tu- mors and tumor-like conditions of the os calcis. Orthop. Clin. North AM, 4: 145-156, 1973.

2) Crocker, A. C.: Textzook of pediatrics, Ed. by Nelson, 11th ed. Saunders, Philadelphia, pp. 1883-1986, 1979.

3) Englbreth-Holm, J. et al. : Eosinophilic granuloma of bone-Schüller-Christian's disease. Acta Med. Scand., 118: 292-312, 1944.

4) Hunter, T.: Solitary eosinophilic granuloma of bone. J. Bone and Joint Surg., 38 B : 545-557, 1956.

5）石川哲夫，他：Reticulohistiocytosis の検討 一多発性 eosinophilic granuloma の自然治療 症を経験して一整形外科, 18: 831-839, 1967.

6) Lahey, M. E.: Histiocytosis X-comparison of three treatment regimens. J. Pediatr., 87: 179-183, 1975.

7) Lahey, M. E.: Histocytosis X-an analysis of prognostic factors. J. Pediatr., 87: 184-189, 1975.

8) Lichtenstein, L.: Histiocytosis $\mathrm{X}$; integration of eosinophilic granuloma of bone, "Letterer Siwe disease" and "SchüllerChristian disease" as related manifestations of single nosologic entity. A. M. A. Arch. Path., 56: 84-102, 1953.

9) Lichtenstein, L.: Histiocytosis X (Eosinophilic Granuloma of Bone, Letterer-Siwe Disease, and Schüller-Christian Disease).J. Bone and Joint Surg., 46 A: 76-90, 1964.

10）野本直記，他：Vinblastine sulfate が著效を 奏した Letterer-Siwe 病の 1 症例. 小児科診療 36: $\varepsilon 24-328,1973$.

11) Schajowicz, F. and Slullite, J.: Eosinophihilic granuloma of bone and its relationship to Hand-Schüller-Christian and Letterer-Siwe Syndrome. J. Bone and Joint Surg., 55 B : 545-565, 1973. 